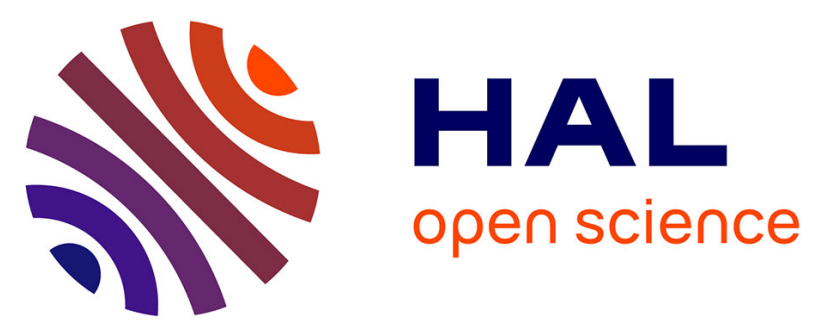

\title{
Environmental risk assessment of carbosulfan on target and non-target beetles when used as white grub larvicide in the cork oak forest of Mamora (Morocco)
}

Rachida Jonsson Fegrouche, N. Kadiri, D. Ghailoule, Z. Atay Atay Kadiri, J.-P. Lumaret

\section{To cite this version:}

Rachida Jonsson Fegrouche, N. Kadiri, D. Ghailoule, Z. Atay Atay Kadiri, J.-P. Lumaret. Environmental risk assessment of carbosulfan on target and non-target beetles when used as white grub larvicide in the cork oak forest of Mamora (Morocco). International Journal of Pest Management, 2014, 60 (1), pp.39-45. 10.1080/09670874.2014.894217 . hal-03348733

\section{HAL Id: hal-03348733 \\ https://hal.science/hal-03348733}

Submitted on 19 Sep 2021

HAL is a multi-disciplinary open access archive for the deposit and dissemination of scientific research documents, whether they are published or not. The documents may come from teaching and research institutions in France or abroad, or from public or private research centers.
L'archive ouverte pluridisciplinaire HAL, est destinée au dépôt et à la diffusion de documents scientifiques de niveau recherche, publiés ou non, émanant des établissements d'enseignement et de recherche français ou étrangers, des laboratoires publics ou privés. 


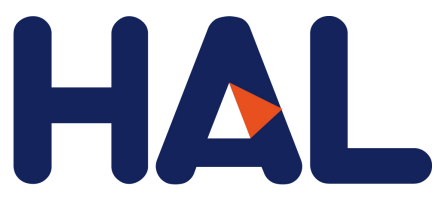

archives-ouvertes

\section{Environmental risk assessment of carbosulfan on target and non-target beetles when used as white grub larvicide in the cork oak forest of Mamora (Morocco)}

Rachida Fegrouche, N. Kadiri, D. Ghailoule, Z. Atay Kadiri, J.-P. Lumaret

\section{To cite this version:}

Rachida Fegrouche, N. Kadiri, D. Ghailoule, Z. Atay Kadiri, J.-P. Lumaret. Environmental risk assessment of carbosulfan on target and non-target beetles when used as white grub larvicide in the cork oak forest of Mamora (Morocco). International Journal of Pest Management, Taylor \& Francis, 2014, 60 (1), pp.39-45. 10.1080/09670874.2014.894217. hal-03348733

\section{HAL Id: hal-03348733 \\ https://hal.archives-ouvertes.fr/hal-03348733}

Submitted on 19 Sep 2021

HAL is a multi-disciplinary open access archive for the deposit and dissemination of scientific research documents, whether they are published or not. The documents may come from teaching and research institutions in France or abroad, or from public or private research centers.
L'archive ouverte pluridisciplinaire HAL, est destinée au dépôt et à la diffusion de documents scientifiques de niveau recherche, publiés ou non, émanant des établissements d'enseignement et de recherche français ou étrangers, des laboratoires publics ou privés. 


\title{
Environmental risk assessment of carbosulfan on target and non-target beetles when used as white grub larvicide in the cork oak forest of Mamora (Morocco)
}

\author{
R. Fegrouche ${ }^{\mathrm{a}, \mathrm{c}}$, N. Kadiri ${ }^{\mathrm{b}}$, D. Ghailoule ${ }^{\mathrm{a}}$, Z. Atay Kadiri ${ }^{\mathrm{c}}$ and J.-P. Lumaret*,b \\ ${ }^{a}$ Centre de Recherches Forestières, Laboratoire d'Entomologie, B.P. 763, Agdal-Rabat, Morocco; ${ }^{b}$ Université Paul-Valéry Montpellier 3 , \\ Laboratoire de Zoogéographie, UMR 5175 CEFE, route de Mende, 34199 Montpellier cedex 5, France; ${ }^{c}$ Laboratoire de Zoologie et Biologie \\ Générale, Faculté des Sciences, Av. Ibn Batouta, B.P. 1014, Université Mohamed V-Agdal, 10000 Rabat, Morocco
}

(Received 29 September 2013; final version received 10 February 2014)

\begin{abstract}
The protection of new cork oak plantations against the larvae of the beetle Sphodroxia maroccana (Melolonthidae), which destroy the roots of newly planted trees, was provided for many years in the forest of Mamora in Morocco by the use of carbosulfan, usually formulated as dry granules for direct incorporation into the soil at planting. Ecotoxicological tests were conducted in the laboratory on S. maroccana and on two non-target beetle species, namely Pachychila obtusecostata and Pimelia platynota (Tenebrionidae), to measure the acute effects of carbosulfan and evaluate the potential risk associated with inappropriate practices. The mortality was measured at both $4 \mathrm{~d}$ and $7 \mathrm{~d}$ after ingestion of a known quantity of carbosulfan. The recommended dose by the manufacturer was exceeded by at least four-fold in the Mamora Forest, with obvious environmental risks. Risks were identified for wildlife when the pesticide is misused and spread on the soil around the plants.
\end{abstract}

Keywords: carbosulfan; cork oak; environmental risk; Melolonthidae; Morocco; mortality; Pachychila obtusecostata; Pimelia platynota; Sphodroxia maroccana; Tenebrionidae

\section{Introduction}

The Mamora Forest $\left(6^{\circ} 00^{\prime}-6^{\circ} 45^{\prime} \mathrm{W} ; 34^{\circ} 00^{\prime}-34^{\circ} 26^{\prime} \mathrm{N}\right)$ in Morocco covers a large area in the region of Salé, Kenitra and Tifelt. This vegetation type is in marked decline (Bouslihim 1996), with many old Quercus suber L. trees in poor condition (most trees are more than one century old) and serious problems in natural regeneration. In the previous century, the forest lost nearly two-thirds of its original area, while in the remaining parts many oak trees declined in number due to great human pressure (e.g. clearing, pruning, stripping, collection of acorns, and domestic animal grazing in the undergrowth), combined with insect attack, including that by gypsy moth (Lymantria dispar [L.]) and cork ant (Crematogaster scutellaris [Olivier]) (Formicidae), as well as several borers, including the beetles Cerambyx cerdo L. (Cerambycidae) and Platypus cylindrus (Fabricius) (Platypodidae) (Fraval and Villemant 1997). Overall, the forest resembles a wooded park planted with even-aged stands of old oak trees, the foliage of which is periodically destroyed below $2 \mathrm{~m}$ by cattle and the lateral branches often pruned for cattle feeding in drought periods. At the end of the twentieth century, the area occupied by cork oaks covered only 60,000 to 70,000 ha (Bendaanoun 1998; Benzyane 1998). In this context, natural regeneration was very difficult and the artificial reconstitution of the forest became necessary (Dahmani 2005). The plantation was soon faced with high mortality of seedlings (from $41 \%$ to $68 \%$ mortality during the first year, depending on the blocks), mostly due to larvae (white grubs) of Sphodroxia maroccana Ley (Melolonthidae) (Montreuil et al. 2004; Ghaioule et al. 2007, 2010). This species is widespread throughout the Mamora Forest as it is endemic to this region, with an outbreaking population mainly due to imbalances of anthropogenic origin (especially domestic animal grazing in the undergrowth and the subsequent disappearance of the grass cover, whose roots normally repulse and divert attacks by white grubs against the roots of young trees) (Ghaioule et al. 2007, 2010). To combat white grubs, the technicians responsible for the forest plantings for many years used carbosulfan before it was replaced by its metabolite carbofuran (OMS-864). Carbosulfan, usually formulated as dry granules (10\%) or microgranules for direct incorporation into the soil at planting, was often misused and spread by technicians on the soil surface around the plants, posing real risks for wildlife that might encounter it. Inadequate understanding of the potential risks that this pesticide posed to the environment, associated with inappropriate practices, resulted not only in high mortality of granivorous birds, but also of many nontarget beetles such as detritivorous darkling beetles (Tenebrionidae) (pers. obs.). Birds died from ingesting the granules, which resemble grain seeds in size and shape, as already reported many times (US EPA 1991, 2006; Almeida et al. 2010). As a result, granular formulations of carbofuran were banned in 1994 by the Environmental Protection Agency to protect the avifauna. Separately, the European Union banned the use of carbosulfan in 2007 (EU 2007).

*Corresponding author. Email: jean-pierre.lumaret@univ-montp3.fr 
Carbosulfan (2,3-dihydro-2, 2-dimethyl-7-benzofuryl [(dibutylamino) thio] methylcarbamate) (CASRN-5528514-8 PubMed) is a carbamate with insecticidal and nematicidal properties that is absorbed by the roots of treated plants and has contact and oral activity. This insecticide has similar toxic mechanisms compared to organophosphates. It blocks transmission of nerve impulses by irreversible inhibition of the enzyme acetylcholinesterase at cholinergic synapses, causing insect death (Fukuto 1990).

The aims of our study were (i) to assess the acute effects of carbosulfan on the larvae of the pest species Sphodroxia maroccana and on two non-target darkling beetles Pimelia platynota Fairmaire and Pachychila obtusecostata subspecies trisulcata Antoine (Tenebrionidae); and (ii) to examine how carbosulfan was used at the time of planting cork oak in Morocco before the recent ban on its use.

\section{Materials and methods}

\subsection{Test species}

Sphodroxia maroccana larvae were collected during winter when they were active near the soil surface (Ghaioule et al. 2007, 2010; Fegrouche et al. 2012a, $2012 b)$. Larvae were reared individually in 2-L capacity plastic boxes filled with sand (130-150 $\mu \mathrm{m}$; Texier et al. 1992) which was kept slightly moist (40-60\% humidity, based on previous experiments; Fegrouche et al. 2012b). Larvae were fed with fragments of potato (which the polyphagous larvae are known to feed on). Ecotoxicological tests were conducted in the laboratory between February and late March 2010, when the feeding activity was highest.

Pimelia platynota and Pachychila obtusecostata are widespread and abundant detritivorous beetles in the Mamora Forest. The ease of maintenance under laboratory makes these non-target species good candidates for toxicity testing. Adults were collected in the spring (March) using pitfall traps (Barber model) buried to their rim in the sandy soil at random locations in different parts of the forest. Individuals were placed in 3-L capacity plastic boxes with $5 \mathrm{~cm}$ of dry sand from the site. The boxes, containing about 30 individuals, were maintained at laboratory temperatures $\left(25 \pm 2^{\circ} \mathrm{C}\right)$ and light-dark regime $14 \mathrm{~h} \mathrm{~L}: 10 \mathrm{~h} \mathrm{D}$. The beetles were fed weekly with a spoonful of flour mixed with bread.

\subsection{Exposure to carbosulfan}

Carbosulfan is not soluble in water. Hence, it was dissolved in acetone to obtain the desired concentrations by serial dilution. Preliminary tests covered a wide concentration range to test lethal and sublethal effects. Test dilutions were prepared from a stock solution containing $250 \mathrm{mg}$ carbosulfan in $50 \mathrm{~mL}$ acetone. Toxicity tests were performed using technical grade carbosulfan (Pestanal ${ }^{\circledR}$, Sigma-Aldrich Company, 94.4\% purity, batch 5137X). The values mentioned below in the text have been adjusted to $100 \%$ purity.
Tests with $S$. maroccana larvae were performed in $400 \mathrm{~mL}$ plastic boxes covered with lids, with one larva per box. Before starting the test, only $0.10 \mathrm{~g}$ of crushed potato, whatever the dose and the size of larvae, was placed at the bottom of each box and the appropriate dose of carbosulfan solution was added to food. Boxes were first left open (without a lid) for $12 \mathrm{~h}$ to allow any residual solvent (acetone) to evaporate, and then $20 \mu \mathrm{l}$ of water were added to obtain optimal moisture for food. The tests with white grubs (large and small larvae were tested separately, 2.7 and $5.7 \mathrm{~g}$, respectively) comprised 10 treatments: 2 controls (water and solvent) and 8 doses of carbosulfan which ranged from 0.047 to $47.2 \mu \mathrm{g}(0.047$; $0.095 ; 1.42 ; 2.36 ; 3.77 ; 4.72 ; 14.16 ; 47.2 \mu \mathrm{g}$ carbosulfan per $0.10 \mathrm{~g}$ food). These values were selected on the basis of a range-finding test performed at nominal carbosulfan concentrations of $0.047,1.42,14.16$ and $47.2 \mu \mathrm{g}$ per $0.10 \mathrm{~g}$ food together with an untreated control and solvent control, using five individuals per concentration. The results of the range-finding test showed that the mortality

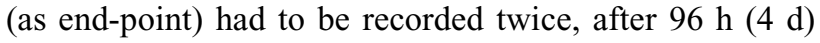
and $168 \mathrm{~h}(7 \mathrm{~d})$. The palatability to larvae of food containing the highest doses of carbosulfan was low, so that more larvae than needed (depending on the dose) were tested in order to have the right number of individuals which would ingest the pesticide in totality (dose-effect relationship regarding the feeding on potato: 2 and 5 more larvae for doses 14.16 and $47.2 \mu \mathrm{g}$ carbosulfan, respectively). Only larvae that had consumed all the food provided containing a known dose of carbosulfan were retained. Therefore, carbosulfan ingested with food was exactly the required dose for each individual. The larvae that refused to feed (or consumed only a part of food) were excluded from the trial, as it was considered that the required dose had not been totally ingested. Ten and 22 larvae of small and large size, respectively, fulfilled these criteria for each dose.

The tests performed with adults of Pimelia and Pachychila comprised 11 treatments: 2 controls (water and solvent) and 9 doses of carbosulfan, ranging from 0.047 to $47.2 \mu \mathrm{g}(0.047 ; 0.47 ; 1.42 ; 2.36 ; 3.77 ; 4.25 ; 4.72 ; 14.16$; $47.2 \mu \mathrm{g}$ carbosulfan). A small piece of bread $(0.10 \mathrm{~g})$ was placed at the bottom of the vessel (Petri dish), and carbosulfan was added to the food to obtain the right dose. As was the case for larvae of $S$. maroccana, the palatability, for darkling beetles, of food containing the highest doses of carbosulfan was low, and more insects were necessary for the experiments. Only individuals that had consumed all the provided food containing a known dose of carbosulfan were retained; beetles that refused to feed (or consumed only a part of food) were excluded from the trial, as it was considered that the required dose had not been not totally ingested by the individuals. Thirty and 27 adults of Pimelia and Pachychila, respectively, were retained for each dose.

All tests were performed at room temperature $(25 \pm$ $2^{\circ} \mathrm{C}$ ) and lasted for $7 \mathrm{~d}$. The numbers of surviving darkling beetles (Pimelia and Pachychila) and S. maroccana (large and small larvae) were recorded daily - the results are given for $4 \mathrm{~d}$ and $7 \mathrm{~d}$ exposures. 
Table 1. Live weight of tested individuals (Sphodroxia maroccana, Pachychila obtusecostata and Pimelia platynota) and comparison of batches, including control and solvent. The normality of groups was tested with the Anderson-Darling test (using the Pearson correlation coefficient).

\begin{tabular}{lccccccc}
\hline Species & $\begin{array}{c}\text { No. } \\
\text { batch }\end{array}$ & $\begin{array}{c}\text { No. individuals } \\
\text { tested/batch }\end{array}$ & $\begin{array}{c}\text { Max. } \\
\text { weight (g) }\end{array}$ & $\begin{array}{c}\text { Min. } \\
\text { weight (g) }\end{array}$ & $\begin{array}{c}\text { Average } \\
\text { weight (g) }\end{array}$ & $\begin{array}{c}\text { Standard } \\
\text { deviation }\end{array}$ & $\begin{array}{c}\text { Normality } \\
\text { of batches }\end{array}$ \\
\hline Sphodroxia larvae (large size) & 10 & 22 & 6.26 & 5.50 & 5.71 & 1.09 & n.s. \\
Sphodroxia larvae (small size) & 10 & 10 & 2.85 & 2.55 & 2.68 & 0.43 & n.s. \\
Pimelia (adults) & 11 & 30 & 1.03 & 0.70 & 0.84 & 0.14 & n.s. \\
Pachychila (adults) & 11 & 27 & 0.15 & 0.08 & 0.10 & 0.07 & n.s. \\
\hline
\end{tabular}

n.s. $=$ not significant.

\subsection{Statistical analysis}

The critical effect and threshold concentration for tests were calculated using Toxrat ${ }^{\circledR}$ software (version 2.10). The LOED (Lowest Observed Effect Dose) and NOED (No Observed Effect Dose) values were determined using Fisher's exact binomial test with Bonferroni correction. The values for doses causing 50\% mortality $\left(\mathrm{LD}_{50}\right)$ with $95 \%$ confidence limits were determined with a Probit analysis, using linear maximum likelihood regression. The tests were considered as valid when the mortality in the controls did not exceed $5.0 \%$. The pairwise comparisons between the two controls (water and solvent) were performed using a Fisher's exact binomial test (alpha $=0.05$; two-sided). In all cases there was no significant difference between control water and solvent, and no mortality at all was observed. The control mortality at $4 \mathrm{~d}$ and $7 \mathrm{~d}$ was compensated using Abbott's formula. To ensure the samples were comparable (the susceptibility of individuals depending in large part on their size), four groups were segregated according to the weight of individuals: darkling beetles (Pimelia and Pachychila) and large and small larvae of $S$. maroccana. The normality of group data was tested with the Anderson-Darling test. (This test measures the least squares distance between the points of the diagram and the regression line. The least squares estimate is calculated using the Pearson correlation coefficient.) Statistical analyses were conducted using Minitab ${ }^{\circledR} 13$ Statistical Software.

\section{Results}

\subsection{Homogeneity of biological material}

All samples were uniform in weight distribution, without significant difference between batches of the same size class (Table 1).

\subsection{Mortality}

The mortality was recorded initially after 4-d exposure to check any changes of activity exhibited by the treated Sphodroxia larvae (small and large size) and adults of the darkling beetles Pimelia and Pachychila. Final mortality was recorded at $7 \mathrm{~d}$ (Table 2). All the tests were valid.

\subsubsection{Sphodroxia larvae}

The first symptoms of poisoning appeared rapidly: between one hour and half a day after ingestion of contaminated food. Larvae vomited large volumes of a dark liquid when the first muscular contractions (curvature of abdomen) appeared. The movements became increasingly erratic and uncoordinated (sublethal). The evolution of symptoms continued with hyperexcitement and convulsions leading finally to paralysis until death of the larvae. After ingestion of carbosulfan, the mortality of larvae varied depending on their size and the doses. After $4 \mathrm{~d}$ exposure, the mortality of small larvae reached $80 \%$ with the ingestion of $3.77 \mu \mathrm{g}$ carbosulfan per $0.1 \mathrm{~g}$ food (Figure 1a). In the case of large larvae, $3.77 \mu \mathrm{g}$ carbosulfan resulted in a mortality of $22.7 \%$; the mortality reached $77.2 \%$ with $14.16 \mu \mathrm{g}$ (Figure 2a). The mortality was $100 \%$ when $47.2 \mu \mathrm{g}$ carbosulfan per $0.1 \mathrm{~g}$ food was ingested, irrespective of the size of larvae. No mortality was observed in the controls (solvent and water). The results showed a clear dose-response relationship in all the tests and significant effects with increased doses of carbosulfan. The $\mathrm{LD}_{50}$ values (median lethal dose with 95\% confidence limits) after $4 \mathrm{~d}$ were 1.63 (95\% CL: $0.73-3.18 \mu \mathrm{g} / 0.1 \mathrm{~g}$ food) and $5.84 \mu \mathrm{g}$ carbosulfan for small and large Sphodroxia larvae, respectively, with an NOED of 0.09 and $2.36 \mu \mathrm{g}$ carbosulfan per $0.1 \mathrm{~g}$ food per

Table 2. Test results (4 d and $7 \mathrm{~d}$ ) with Sphodroxia maroccana larvae (small and large larvae) and with Pachychila obtusecostata and Pimelia platynota adults (data in $\mu \mathrm{g}$ carbosulfan / $0.1 \mathrm{~g}$ food). Lethal dose $\mathrm{LD}_{50}(50 \%$ effect) including the $95 \%$ confidence limits (CL) in parentheses, and NOED and LOED values.

\begin{tabular}{|c|c|c|c|c|c|c|}
\hline \multirow[b]{2}{*}{ Species } & \multicolumn{3}{|c|}{$0-4$ days } & \multicolumn{3}{|c|}{$0-7$ days } \\
\hline & $\mathrm{LD}_{50}(95 \% \mathrm{CL})$ & $\operatorname{NOED}(\mu \mathrm{g})$ & $\operatorname{LOED}(\mu \mathrm{g})$ & $\mathrm{LD}_{50}(95 \% \mathrm{CL})$ & $\operatorname{NOED}(\mu \mathrm{g})$ & $\operatorname{LOED}(\mu \mathrm{g})$ \\
\hline Sphodroxia (small larvae) & $1.63(0.73-3.18)$ & 0.09 & 1.42 & $1.50(0.67-2.88)$ & 0.09 & 1.42 \\
\hline Sphodroxia (large larvae) & $5.84($ n.d) & 2.36 & 3.77 & 4.44 (n.d.) & 2.36 & 3.77 \\
\hline Pachychila (adults) & $3.30(2.22-4.85)$ & 0.47 & 1.42 & $2.86(1.93-3.97)$ & 0.47 & 1.42 \\
\hline Pimelia (adults) & $4.53(2.7-9.61)$ & 2.36 & 3.77 & $3.97(2.48-6.82)$ & 0.47 & 1.42 \\
\hline
\end{tabular}

n.d. $=$ not determined. 

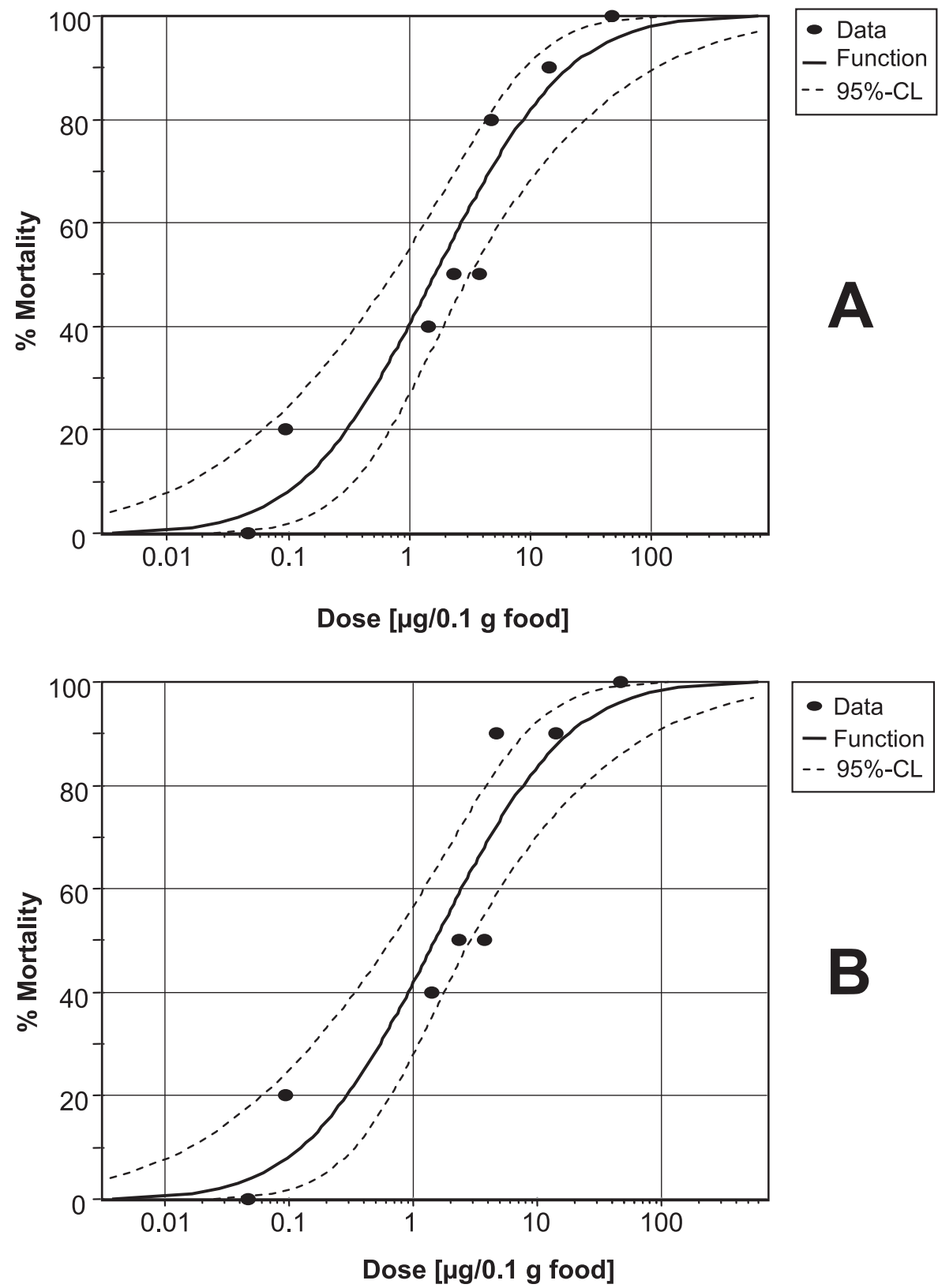

- Data

- Function

- - 95\%-CL

B

Figure 1. Concentration-effect curves showing the effect of carbosulfan ( $\mu \mathrm{g} / 0.1 \mathrm{~g}$ food) on mortality (\%) of small Sphodroxia maroccana larvae. A: $4 \mathrm{~d}$ after ingestion; B: $7 \mathrm{~d}$ after ingestion.

larva for small and large individuals, respectively (Table 2).

After $7 \mathrm{~d}$ exposure, the probit analysis revealed $\mathrm{LD}_{50}$ values of $1.50(0.67-2.88)$ and $4.44 \mu \mathrm{g}$ carbosulfan per $0.1 \mathrm{~g}$ food per larva for small and large individuals, respectively. The NOED was 0.09 and $2.36 \mu \mathrm{g}$ carbosulfan per $0.1 \mathrm{~g}$ food per larva for small and large individuals, respectively (Table 2). Between the endpoints at $4 \mathrm{~d}$ and $7 \mathrm{~d}$, the NOED and LOED values remained unchanged, both for small and large larvae. The doseeffect varied according to the size (Figures $1 \mathrm{~b}$ and $2 \mathrm{~b}$ ). When $\mathrm{LD}_{50}$ values were reported to the same body weight (1 kg body weight), the susceptibility of small larvae was higher than for large larvae. At $4 \mathrm{~d}$ post-ingestion, the $\mathrm{LD}_{50}$ was $583 \mu \mathrm{g}$ carbosulfan per $\mathrm{kg}$ small larvae compared to $1023 \mu \mathrm{g}$ carbosulfan per $\mathrm{kg}$ large larvae.
Similarly, at $7 \mathrm{~d}$ post-ingestion, $\mathrm{LD}_{50}$ values were $560 \mu \mathrm{g}$ carbosulfan per kg small larvae against $777 \mu \mathrm{g}$ carbosulfan per $\mathrm{kg}$ large larvae. For comparison, the oral $\mathrm{LD}_{50}$ in rats is $250 \mathrm{mg}$ carbosulfan per kg body weight; (Dawson et al. 2010).

\subsubsection{Darkling beetles}

The behavioural sequence observed in adults of Pimelia and Pachychila post-ingestion was similar to that reported above for Sphodroxia larvae. In both species, the first symptoms of poisoning appeared immediately after consuming toxic food. The insects vomited a more or less brownish liquid and displayed dysfunctional locomotion and phases of hyper-excitement, leading to complete paralysis and death of individuals. After $4 \mathrm{~d}$ exposure, 


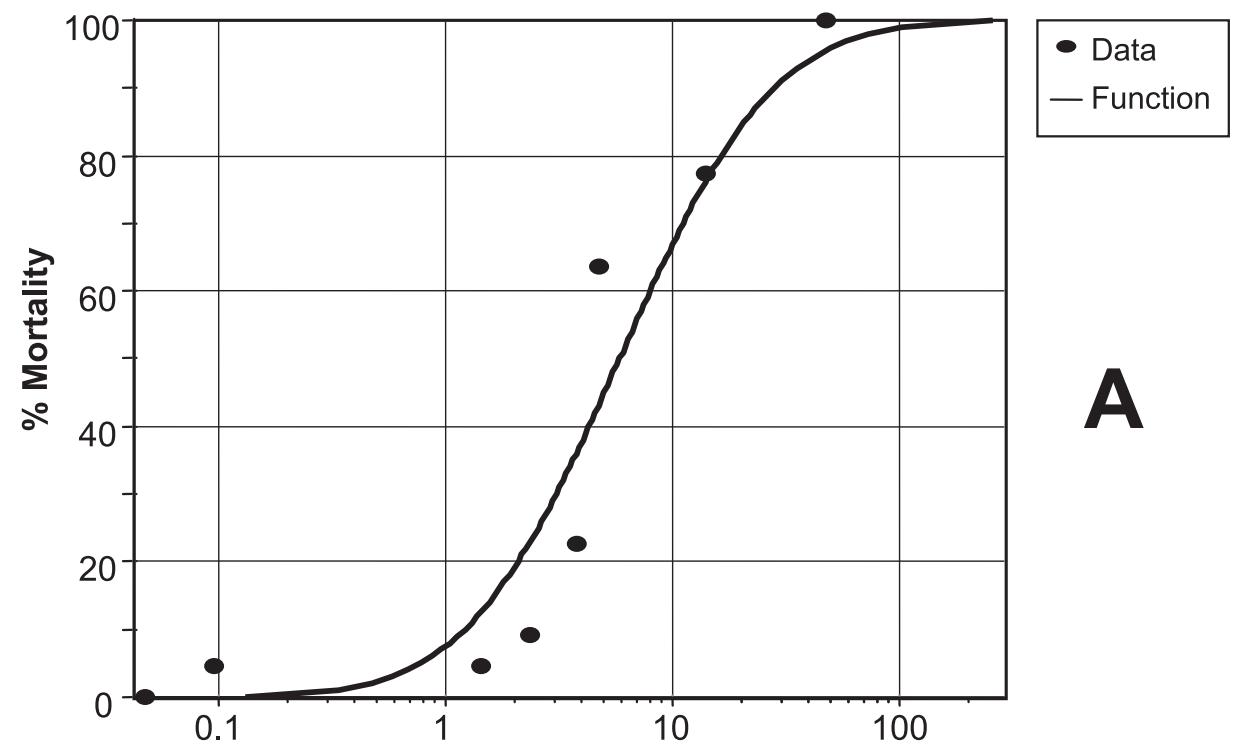

Dose $[\mu \mathrm{g} / 0.1 \mathrm{~g}$ food]

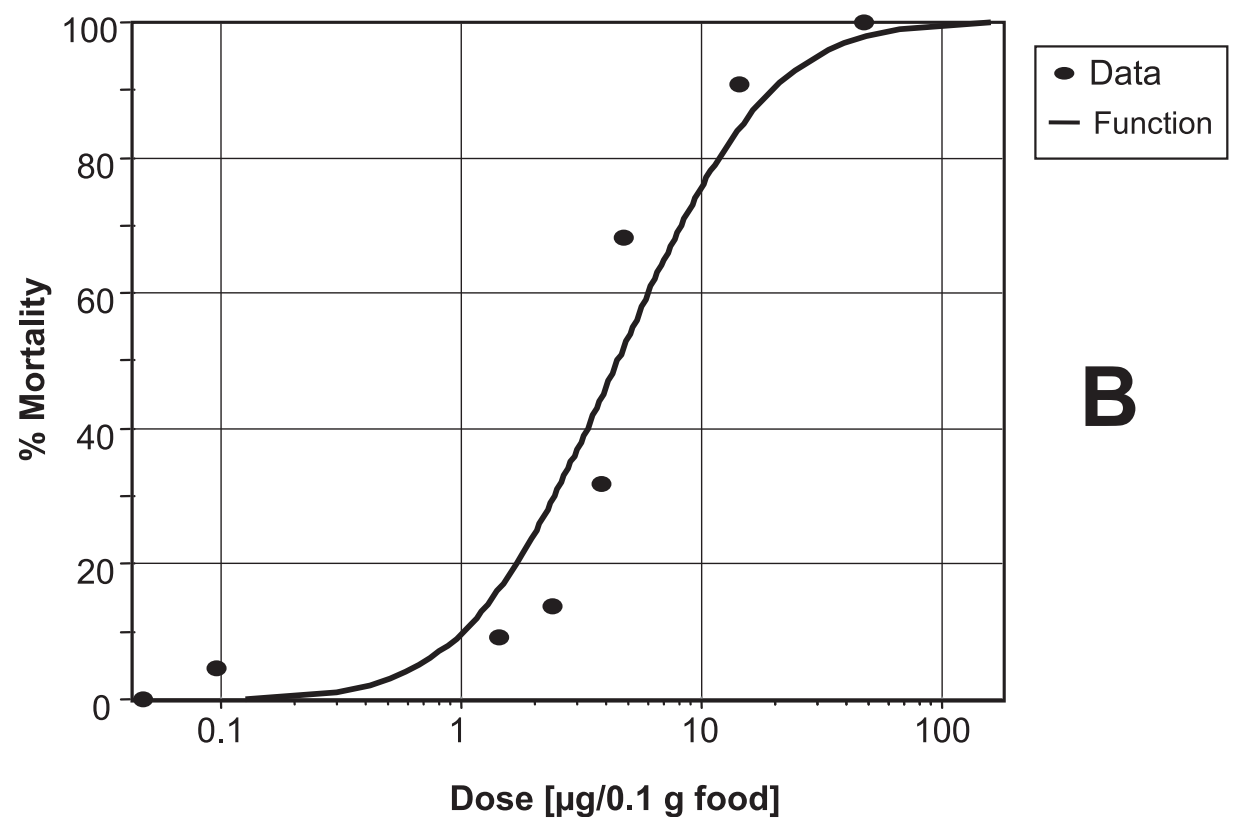

Figure 2. Concentration-effect curves showing the effect of carbosulfan ( $\mu \mathrm{g} / 0.1 \mathrm{~g}$ food) on mortality (\%) of large Sphodroxia maroccana larvae. A: $4 \mathrm{~d}$ after ingestion; B: $7 \mathrm{~d}$ after ingestion.

Pimelia beetles remained as active as in controls after ingestion of $0.047 \mu \mathrm{g}$ carbosulfan per $0.1 \mathrm{~g}$ food. The first symptoms appeared with a dose 10 -fold higher $(0.47 \mu \mathrm{g} /$ $0.1 \mathrm{~g}$ food), which corresponds to the LOED value. 53.3\% mortality was obtained with the absorption of $4.72 \mu \mathrm{g}$ carbosulfan present in $0.1 \mathrm{~g}$ food, and mortality of all individuals with a dose of $14.16 \mu \mathrm{g}$ carbosulfan in $0.1 \mathrm{~g}$ food, which corresponds to $14.16 \mu \mathrm{g}$ carbosulfan ingested by each individual. As for Pimelia, $0.047 \mu \mathrm{g}$ carbosulfan in $0.1 \mathrm{~g}$ food had no significant effect on Pachychila beetles. After $4 \mathrm{~d}$, the mortality reached $55.6 \%$ with ingestion of $4.25 \mu \mathrm{g}$ carbosulfan per $0.1 \mathrm{~g}$ food, and $100 \%$ with $14.16 \mu \mathrm{g}$ carbosulfan per $0.1 \mathrm{~g}$ food.

At low doses (3.77 $\mu \mathrm{g}$ carbosulfan/0.1 g food), the resistance of Pachychila beetles and Sphodroxia small larvae was not significantly different, with $44.5 \%$ and $50.0 \%$ mortality, respectively. At higher doses the species susceptibility was different: $100 \%$ mortality was attained with $14.16 \mu \mathrm{g}$ carbosulfan per $0.1 \mathrm{~g}$ food for Pachychila, and $47.2 \mu \mathrm{g}$ carbosulfan per $0.1 \mathrm{~g}$ food for Sphodroxia small larvae. The type of food (potato for Sphodroxia larvae; bread for darkling beetles) was not of particular importance in so far as food was completely consumed by individuals ( $0.1 \mathrm{~g}$ food in all cases) and was used only to allow ingestion of carbosulfan. LD $_{50}$ values $(95 \% \mathrm{CL})$ calculated for Pachychila and Pimelia after $4 \mathrm{~d}$ were 3.30 and $4.53 \mu \mathrm{g}$ carbosulfan, respectively, with NOED values of 0.47 and $2.36 \mu \mathrm{g}$ carbosulfan for Pachychila and Pimelia, respectively (Table 2$)$. $\mathrm{LD}_{50}$ values $(95 \% \mathrm{CL})$ after $7 \mathrm{~d}$ post-ingestion were lower when compared to $4 \mathrm{~d}$ 
values, with 2.86 and $3.97 \mu \mathrm{g}$ carbosulfan per individual for Pachychila and Pimelia, respectively, with the same values for NOED $(0.47 \mu \mathrm{g}$ carbosulfan $/ 0.1 \mathrm{~g}$ food) (Table 2). If $\mathrm{LD}_{50}$ values were reported to the same body weight (bw) in kilograms (for comparison with other species), the difference in susceptibility was significant: 33.00 and $5.39 \mathrm{mg}$ carbosulfan per $\mathrm{kg}$ bw for Pachychila and Pimelia, respectively at $4 \mathrm{~d}$, and 28.60 and $4.73 \mathrm{mg}$ carbosulfan per $\mathrm{kg}$ bw, respectively, after $7 \mathrm{~d}$.

\section{Discussion}

Carbosulfan is an insecticide that has been widely used in agriculture and forestry. In its dry granule formulation, it has been recommended by the manufacturers for use against many pests. It was used, for example, against the pine bark beetle Hylaster ater (Paykul) (Scolytinae) which compromised forest regeneration of Pinus radiata D. Don in New Zealand (Reay and Walsh 2002a; Reay et al. 2012), but is no longer in operational use (Reay and Walsh $2002 \mathrm{~b}$ ). Other studies have demonstrated the efficacy of carbosulfan against Hylaster ater (Lempérière and Julien 1989; Mrlina et al. 1994; Heritage et al. 1997) and against the large pine weevil Hylobius abietis (L.) (Lempérière and Julien 2003). This carbamate was also used against wireworms (elaterid beetle larvae) in corn and against the larvae of common cockchafer beetle Melolontha melolontha (Scarabaeidae) (Bednarek et al. 2004). Other studies have confirmed the efficacy of carbosulfan against pyrethroid-resistant mosquitoes (Guillet et al. 2001).

Correct utilization of carbosulfan in regeneration plots at the Mamora Forest reduced significantly the damage by $S$. marocana larvae. During a field test campaign, the mortality of seedlings under carbosulfan protection (the granules were buried,in contact with the roots) was $8.3 \%$ against $73.5 \%$ for the controls (untreated seedlings) (Ghaioule et al. 2010). According to our results, $\mathrm{LD}_{50}$ values ranged between 1.63 and $5.84 \mu \mathrm{g}$ carbosulfan per larva after $4 \mathrm{~d}$ and between 1.50 and $4.44 \mu \mathrm{g}$ carbosulfan per larva after $7 \mathrm{~d}$ for small and large $S$. maroccana larvae, respectively. The recommended dose by the manufacturer, intended to prevent damage by white grubs when planting, was $10 \mathrm{~g}$ carbosulfan granules per seedling (Reay and Walsh 2002b; Ghaioule et al. 2010). However, most often in the Mamora Forest this recommended dose was exceeded by the forest technicians by at least four-fold ( $42 \mathrm{~g}$ granules per seedling carbosulfan $10 \%$, i.e. $4.2 \mathrm{~g}$ active substance), with obvious environmental risks (pers. obs.).

The protection of seedlings is necessary for at least four years so that trees attain a sufficient size to resist damage by white grubs (Ghaioule et al. 2007). The results of our experiment showed that the dose recommended by the manufacturer is still high and should be reduced to half. It is crucial that the use of insecticides in granular form has to be accurate, whatever compound may be recommended for plantations in the Mamora Forest. Under normal conditions, the incorporation of granules at the root level (about $50 \mathrm{~cm}$ deep, allowing the transfer of the systemic pesticide into the plant) is essential to prevent birds and other non- target organisms having access to granules (Almeida et al. 2011). However, several cases of granules misuse have been observed in the Mamora Forest (pers. obs.). Some technicians were casting granules over the soil surface, or arranging them in a circle around the seedlings. In both cases this procedure is completely ineffective because white grubs move back and forth into the soil at the interface between dry and moist sand (Fegrouche et al. 2012b). As a consequence, mortality of many non-target insects was observed at the soil surface (mostly darkling beetles) and granules were consumed by granivorous birds. Even though the incorporation of granules into the soil reduces the risk to the non-target fauna living on the soil surface, the organisms living into the soil, such as darkling beetles larvae, can be adversely affected. In this forest, the density of $S$. maroccana was particularly low when the degree of aridity of soils or climate was high. The highest white grub densities were observed in sites where the soils showed the highest capacity to retain water (Ghaioule et al. 2007; Fegrouche et al. 2012a). Only these sites would merit chemical protection of seedlings.

In arid ecosystems, darkling beetles constitute a key group in the use and recycling of plant litter but their beneficial role may be threatened by the widespread use of pesticides. Bad practices are not compatible with the conservation of the environment and the organisms that provide vital ecological services. Our results confirmed the high toxicity of carbosulfan against white grubs and side effects on non-target species. It is not surprising that carbosulfan was banned in Europe in 2008 and in Morocco in 2011. Sphodroxia maroccana constitutes an excellent example of a discrete species, previously present at low density ("low noise" species) in the forest ecosystem, which has become a pest in recent decades because of imbalances related to human activities. In the future, the challenge for forest technicians will be to control this endemic species without complete eradication. For now, this control is achieved using mainly pesticides. Alternative methods are being tested, for example: plantations in alternate rows by keeping the natural vegetation intact; chemical treatments restricted to areas at risk where larval densities are the highest.

\section{Acknowledgements}

This research was supported by the French Ministry of Foreign Affairs and the Moroccan Ministry of Agriculture, Rural Development, Water and Forests (Programs of Agronomic Research for Development PRAD No. 07-01 and 10-07). We thank Dr Harold Labrique (Museum of Lyon, France) for his help in the identification of the Tenebrionidae specimens. The authors are highly appreciative of the useful comments of Gregory T. Sullivan (University of Queensland, Brisbane, Australia) who revised the English of earlier and revised versions of the text. Finally we thank Mark A. Jervis and the two anonymous reviewers whose comments improved the manuscript considerably.

\section{References}

Almeida A, Zarate do Couto HT, Almeida AF. 2010. Camouflaging of seeds treated with pesticides mitigates the 
mortality of wild birds in wheat and rice crops. Scientia Agricola (Piracicaba, Brazil). 67:176-182.

Almeida A, Zarate do Couto HT, Almeida AF. 2011. Camouflage of seeds, a control method of the bird mortality in grain crops. In: Stoytcheva M, editor. Pesticides in the modern world - risks and benefits. Rijeka (Croatia): InTech publisher. p. 363-390.

Bednarek A, Popowska-Nowak E, Pezowicz E, Kamionek M. 2004. Integrated methods in pest control: effect of insecticides on entomopathogenic fungi (Beauveria bassiana (Bals.) Vuill., B. brongniartii (Sacc.)) and nematodes (Heterorhabditis megidis Poinar, Jackson, Klein, Steinernema feltiae Filipjev, S. glaseri Steiner). Polish J Ecol. 52:223-228.

Bendaanoun M. 1998. Contribution à l'étude des facteurs écologiques, de l'impact de la dégradation et des aménagements sur la régénération des subéraies du Rif, du Moyen Atlas oriental et de la Mamora (Maroc septentrional). Actes séminaire méditerranéen sur la régénération des forêts de chêne-liège, Tabarka (Tunisie), 22-24 octobre 1996. Annales INRGREF (special issue):176-197.

Benzyane M. 1998. La subéraie marocaine, produit économique et social à développer. Actes séminaire méditerranéen sur la régénération des forêts de chêne-liège, Tabarka (Tunisie), 22-24 octobre 1996. Annales INRGREF (special issue): $12-21$.

Bouslihim A. 1996. Contribution à l'étude socio-économique des composantes de la filière liège au Maroc. PhD thesis, Mohammed V University, Faculté Sciences Juridiques et Economiques, Rabat, Maroc.

Dahmani J. 2005. Etude de la régénération naturelle et artificielle du chêne-liège (Quercus suber L.) dans les forêts de la Mamora et de Témara (Maroc). PhD thesis Floristique-Ecologie végétale, Ibn Tofail University, Faculté des Sciences, Kénitra (Maroc).

Dawson AH, Eddleston M, Senarathna L, Mohamed F, Gawarammana I, Bowe SJ, Manuweera G., Buckley NA. 2010. Acute human lethal toxicity of agricultural pesticides: a prospective cohort study. PLoS Med. 7(10):e1000357. doi:10.1371/journal.pmed.1000357.

European Union Decision. 2007. Commission Decision of 13 June 2007 concerning the non-inclusion of carbosulfan in Annex I to Council Directive 91/414/EEC and the withdrawal of authorizations for plant protection products containing that substance. Document number C (2007) 2463), 2007/415/EC, Official J Eur Union 16.6.2007.

Fegrouche R, Ghaioule D, Lumaret JP, Atay-Kadiri Z. 2012a. Densités larvaires, comportement et cycle biologique de Sphodroxia maroccana, un ravageur endémique de la subéraie de la Mamora au Maroc (Coleoptera, Melolonthidae). Integrated protection in Quercus spp. forests. IOBC/wprs Bull. 76:205-212.

Fegrouche R, Ghaioule D, Lumaret JP, Bertrand M, Atay-Kadiri Z. 2012b. Etude de la mobilité souterraine des larves de Sphodroxia maroccana (Coleoptera, Melolonthidae), un ravageur des jeunes plants de chênes-lièges dans la forêt de la Mamora (Maroc). Integrated protection in Quercus spp. forests. IOBC/wprs Bull. 76:213-220.

Fraval A, Villemant C. 1997. La Mamora et ses ennemis. Dossiers Environnement INRA Forêts 15:133-146. Available at: http://www.inra.fr/dpenv/d15mamor. htm [accessed on 28 October 2012].
Fukuto TR. 1990. Mechanism of action of organophosphorus and carbamate insecticides. Environ Health Perspec. 87:245-254.

Ghaioule D, El Antry-Tazi1 S, Atay-Kadiri Z, Lumaret JP. 2010. Dégâts des vers blancs dans les jeunes plantations de chêneliège en forêt de la Mamora: biologie de la principale espèce Sphodroxia maroccana Ley (Coleoptera; Melolonthidae) et proposition de méthode de lutte chimique. Integrated protection in oak forests. IOBC/wprs Bull. 57:115-122.

Ghaioule D, Lumaret JP, Rochat D, Maatouf N, Niogret J. 2007. Evaluation des dégâts par les vers blancs (Coleoptera: Scarabaeoidea) dans les parcelles de régénération du chêne-liège (Quercus suber L.) en forêt de la Mamora (Maroc) et recherche de médiateurs chimiques pour une lutte biologique. Ann Soc Entomol France (n.s.) 43:1-8.

Guillet P, N'Guessan R, Darriet F, Traore-Lamizana F, Chanre P, Carnevale P. 2001. Combined pyrethroid and carbamate "two-in-one" treated mosquito nets: field efficacy against pyrethroid-resistant Anopheles gambiae and Culex quinquefasciatus. Med Vet Entomol. 15:102-112.

Heritage S, Johnson D, Jennings T. 1997. The use of Marshal/ suSCon granules to protect plants from Hylobius damage. For Comm Tech Dev Branch, Res Inform Note. 269:1-4.

Lempérière G, Julien J. 1989. Premiers résultats de tests pour l'évaluation de l'efficacité d'un insecticide systémique contre l'Hylobe. Rev For Française. 40:411-422.

Lempérière G, Julien J. 2003. Protection contre l'Hylobe du Pin: efficacité d'un insecticide systémique à base de carbosulfan. Rev For Française. 55:129-140.

Minitab $^{\circledR} 13$ Statistical Software, Minitab Inc., State College, PA 16801, USA. Available at: http://www.minitab.com

Montreuil O, Ghaioule D, Maatouf N, Rochat D, Lumaret JP. 2004. Biologie de Sphodroxia maroccana Ley et description de la femelle de ce nouveau ravageur forestier (Coleoptera, Melolonthidae). Bull Soc Entomol France. 109:317-321.

Mrlina G, Lempérière G, Calmon JP. 1994. Determination and uptake of carbosulfan and carbofuran in young Douglas firs (Pseudotsuga menziesii Mirb.). J Agr Food Chem. 42:15691571.

Reay SD, Walsh PJ. 2002a. The incidence of seedling attack and mortality by Hylaster ater (Coleoptera: Scolytidae) in second rotation Pinus radiata forests in the Central North Island, New Zealand. NZ J For. 47:19-23.

Reay SD, Walsh PJ. 2002b. A carbosulfan insecticide to protect pine seedlings from Hylastes ater (Coleoptera: Scolytidae) damage. NZ J For. 55:80-84.

Reay SD, Glare TR, Brownbridge M. 2012. Hylastes ater (Curculionidae: Scolytinae) affecting Pinus radiata seedling establishment in New Zealand. Psyche, 2012. Article ID 590619, 9 p. URL: http://dx.doi.org/10.1155/2012/590619

Texier JP, Lefêvre D, Raynal JP. 1992. La formation de la Mamora. Le point sur la question du Moulouyen et du Salétien du Maroc nord-Occidental. Quaternaire. 3(2):63-73.

ToxRat ${ }^{\circledR}$ Professional, version 2.10 .05 (released 20.02.10). Software for the statistical analysis of biotests. Copyright (C) 2001-2010. Toxrat Solutions GmbH, Alsdorf, Germany.

US Environmental Protection Agency. 1991. Environmental Fact Sheet for Carbofuran. Office of Pesticides and Toxic Substances, US EPA, Washington, DC. Available at: http://pmep.cce.cornell. edu/profiles/extoxnet/carbaryl-dicrotophos/carbofuran-ext.html

Environmental Protection Agency. 2006. Facts Carbofuran, EPA 738-F-06-024:1-4. 